Plant Tissue Cult. \& Biotech. 26(1): 67-75, 2016 (June)

$\underline{\mathrm{PTC} \& \mathrm{~B}}$

\title{
In vitro Regeneration of Sweetgourd (Cucurbita moschata Duch.)
}

\author{
M. Rezwan Kabir*, M. A. Yousuf Akhond, M. Al-Amin and \\ M. Shahidul Haque ${ }^{1}$
}

Biotechnology Division, Bangladesh Agricultural Research Institute, Gazipur-1701, Bangladesh

Key words: Cotyledon, Cucurbita moschata, Regeneration, Sweetgourd

\begin{abstract}
Cotyledon explants of sweetgourd (Cucurbita moschata Duch.) were cultured on MS supplemented with different concentrations of BAP alone and in combination with NAA, TDZ and 2,4-D. High shooting frequency (94.4\%) was obtained from BARI Mistikumra-1 when cotyledon segments were cultured on MS with 4.44 $\mu \mathrm{M}$ BAP alone. The highest number (8.9) of shoot development and minimum days (14.7) required for shoot induction were also observed in $4.44 \mu \mathrm{M}$ BAP treatment for BARI Mistikumra-1. In contrast, $83.3 \%$ shooting frequency were observed from BARI Mistikumra-2 producing 11.9 shoots in 8.4 days on $8.88 \mu \mathrm{M}$ BAP. The regenerated shoots of both varieties were rooted on half strength of MS and MS supplemented with $0.53 \mu \mathrm{M}$ NAA and $2.46 \mu \mathrm{M}$ IBA. Rooting was observed in BARI Mistikumra- 1 with $92.6 \%$ frequency in 12.3 days whereas it took 8.6 days with $93.3 \%$ rooting frequency in BARI Mistikumra-2 when shoots were cultured on MS supplemented with $0.53 \mu \mathrm{M}$ NAA. Welldeveloped rooted plantlets were transferred to pots containing sterile soil and covered with polythene bags in the greenhouse for hardening. The acclimated plants were planted in the field after three weeks.
\end{abstract}

\section{Introduction}

The Cucurbitaceae is a large family with a number of valuable edible vegetable crops in the tropics, subtropics and many other regions around the world. Among them sweetgourd (Cucurbita moschata Duch.) is the most accepted one for a number of reasons ranging from agricultural purposes to commercial and ornamental sales. Besides the edible fruits, immature fleshy green leaves, tender

*Author for correspondence: <rezwan.kabir@yahoo.com>. ${ }^{1}$ Department of Biotechnology, Bangladesh Agricultural University, Mymensingh, Bangladesh. 
shoots and male flowers are used as vegetables and contain appreciable amounts of vitamins and minerals (Robinson and Walters 1997). Thus, it has the potentiality to contribute substantially in solving the malnutrition problems and thus, improvement of the sweetgourd crop and development of new varieties are necessary. However, there are many agricultural problems in the cultivation of sweetgourd for which conventional breeding often does not have ready answers and the current partial solution is the increasing use of agrochemicals against pests. The crop is affected by several viruses such as - Zucchini yellow mosaic virus (ZYMV), Watermelon mosaic virus (WMV), Papaya ringspot virus $\mathrm{W}$ (PRSV-W), and Cucumber mosaic virus (CMV) (Zitter et al. 1996) along with some fungal diseases. Development of this crop to resist various pests and diseases while improving its growth and vigor would be of considerable commercial value. Biotechnology may play a key role in helping researchers by solving certain breeding problems in this crop. Plant genetic transformation is a viable way for crop improvement but its use requires a reliable and efficient in vitro culture system (Debeaujon and Branchard 1993). Despite its importence, this species has not been subjected to sufficient genetic or biotechnological investigations.

Plant regeneration of Cucurbita species has been reported previously through direct and indirect organogenesis. Carol et al. (1995) also reported the formation of somatic embryos in six squash cultivars (C. pepo) through the use of cotyledon segments. Similarly, squashes (C. pepo and C. maxima) could be regenerated via direct organogenesis using cotyledons (Ananthakrishnan et al. 2003, Lee et al. 2003). But reports on in vitro regeneration of sweetgourd (C. moschata) through tissue culture are rare (Zhang 2008, Zhao 1999, Hegazi 1999). Lack of protocol for effective plant regeneration of this crop may be one of the reasons behind very limited study on its successful stable transformation. Hence, the objective of this study was to establish an efficient regeneration protocol using two popular sweetgourd cultivars aiming at future genetic transformation.

\section{Materials and Methods}

Fresh, uniform and healthy seeds of sweetgourd cultivars BARI Mistikumra 1 and BARI Mistikumra-2 were collected and sterilized for 12 - 15 minutes in 1\% (v/v) sodium hypochlorite containing 3 - 4 drops Tween 20 in a laminar air flow cabinet. Afterwards, they were rinsed 4 times with sterile distilled water at 5 minutes interval and placed in test tubes containing half strength of MS with 30 $\mathrm{g} / \mathrm{l}$ sucrose, vitamins and $8.5 \mathrm{~g} / \mathrm{l}$ agar. The $\mathrm{pH}$ of the medium was adjusted to 5.8 and autoclaved at $121^{\circ} \mathrm{C}, 15$ psi for $20 \mathrm{~min}$. Initially the cultures were kept in 
dark for germination and after two days, transferred into a growth chamber maintained at $24 \pm 2^{\circ} \mathrm{C}$ under a $16 / 8 \mathrm{hrs}$ (light/dark) photoperiod.

Cotyledons were carefully excised from in vitro grown seedlings and placed on sterile Petri dishes or hard papers. Each cotyledon was cut off close to the hypocotyl and then cut across in half with the distal parts discarded as the distal end of cotyledons was not found to produce any shoots in a previous study (Ananthakrishnan et al. 2003). The proximal parts were cut in half with each part having a part of the stalk attached. The apical bud of the seedlings was removed carefully from the explants. Explants of both the cultivars were placed on MS without growth regulators (control) and with different concentrations of BAP $(2.22,4.44,6.66$ and $8.88 \mu \mathrm{M}), \mathrm{BAP}$ and NAA in combinations $(4.44+0.53,8.88+$ $0.53,22.20+0.53$ and $0.44+5.30 \mu \mathrm{M})$, TDZ $(0.23,0.45,2.25$ and $4.50 \mu \mathrm{M})$ and 2,4-D (2.26, 4.52, 6.78 and $9.04 \mu \mathrm{M})$, respectively. The explants were subcultured in MS having five different concentrations of BAP for further multiplication. Four explants were placed on each Petri dish $(15 \times 90 \mathrm{~mm})$ containing about 30 $\mathrm{ml}$ medium. The Petri dishes were sealed with Parafilm and kept at $25 \pm 1^{\circ} \mathrm{C}$ under a 16/8 hrs (day/night) photoperiod with a light intensity of 1500 lux and sub-cultured every 14 days on the same medium and kept under the same conditions. When shoots attained a height of $2.0-2.5 \mathrm{~cm}$, they were cleaned, excised and transferred to half strength of MS, MS supplemented with $2.46 \mu \mathrm{M}$ IBA and $0.53 \mu \mathrm{M}$ NAA for root induction. Well developed rooted shoots were transferred to pots in sterile soil and enclosed with polythene bags to maintain high humidity. The plantlets were kept in the greenhouse and watered once or twice in a week while keeping in covered conditions. After 2 - 3 weeks, bags were removed and the plantlets were transferred to larger pots for further growth.

The experiment was set up in a CRD with three independent replicates. The analysis of variance for different parameters was performed and the means were compared by R programme using STAR software at $5 \%$ level of significance.

\section{Results and Discussion}

The study was conducted by culturing cotyledon explants obtained from 8-10 days old in vitro grown seedlings. Shoots initiated directly from the joint between hypocotyl and cotyledon within 25 days. Multiple shoots originated solely from the proximal part of cotyledon and this result indicated that organogenic competent cells were restricted to this part of the cotyledon. Similar observations had also been reported for other species of Cucurbita (Gambley and Dodd 1990, Compton 2000, Lee et al. 2003, Ananthakrishnan et al. 2003). 
Experiments were carried out to study the effects of MS with different concentrations of growth regulators on regeneration of cotyledon explants (Table 1). The results showed that the explants cultured on MS with BAP and TDZ produced adventitious shoots whereas medium supplemented with 2,4-D and BAP in combination with NAA produced only callus. Explants on control medium did not show any response and a lower percentage of shooting was observed from BAP in combination with NAA in both varieties (Table 1). The results showed that the shooting response was highly variable in different concentrations of BAP and TDZ (Table 1). Previously, Abrei and Staden (2001) observed that TDZ did not improve the shoot production in cucurbits. It has

Table 1. Response of sweetgourd cotyledons on media supplemented with different concentrations of plant growth regulators (mean values).

\begin{tabular}{|c|c|c|c|c|c|}
\hline \multirow{2}{*}{\multicolumn{2}{|c|}{$\begin{array}{l}\text { Conc. } \\
(\mu \mathrm{M})\end{array}$}} & \multicolumn{2}{|c|}{ BARI Mistikumra-1 } & \multicolumn{2}{|c|}{ BARI Mistikumra-2 } \\
\hline & & $\%$ of response & Type of response & $\%$ of response & Type of response \\
\hline Contrc & & 0.0 & - & 0.0 & - \\
\hline \multicolumn{6}{|l|}{ BAP } \\
\hline 2.22 & & 79.2 & S & 66.7 & $\mathrm{~S}$ \\
\hline 4.44 & & 89.9 & $\mathrm{~S}$ & 75.0 & $\mathrm{~S}$ \\
\hline 6.66 & & 76.4 & $\mathrm{~S}$ & 100.0 & $\mathrm{~S}$ \\
\hline 8.88 & & 68.6 & $\mathrm{~S}$ & 100.0 & $\mathrm{~S}$ \\
\hline BAP & NAA & & & & \\
\hline 4.44 & 0.53 & 100.0 & $\mathrm{C}$ & 100.0 & C \\
\hline 8.88 & 0.53 & 100.0 & C & 25.0 & CS \\
\hline 22.20 & 0.53 & 50.0 & CS & 12.5 & CS \\
\hline 0.44 & 5.30 & 75.0 & $\mathrm{C}$ & 50.0 & $\mathrm{C}$ \\
\hline \multicolumn{6}{|c|}{ TDZ } \\
\hline 0.23 & & 52.8 & $S$ & 75.0 & $S$ \\
\hline 0.45 & & 63.9 & $S$ & 50.0 & S \\
\hline 2.25 & & 72.2 & S & 41.7 & S \\
\hline 4.50 & & 44.4 & S & 50.0 & S \\
\hline \multicolumn{6}{|l|}{ 2,4-D } \\
\hline 2.26 & & 88.9 & $\mathrm{C}$ & 88.9 & C \\
\hline 4.52 & & 100.0 & $\mathrm{C}$ & 100.0 & C \\
\hline 6.78 & & 100.0 & C & 88.9 & C \\
\hline 9.04 & & 100.0 & C & 100.0 & C \\
\hline
\end{tabular}

S - shoot, C - callus, CS - callus with shoots.

been also reported that the use of high doses of TDZ had negative effects on organogenesis (Pal et al. 2007). On the other hand, the use of either TDZ or the combination of BAP and NAA caused a drastic decrease in the frequency of explants with shoot buds of watermelon (Krug et al. 2005). The importance of BAP for organogenesis had been studied in cucurbits (Curuk et al. 2002, Lee et al. 
2003) and it was mentioned as an exclusive requirement for shoot formation. BAP was also reported superior to TDZ (Ficcadenti and Rotino 1995) for melon (Cucumis melo). Therefore, four different concentrations of BAP were used in this study to further optimize the regeneration protocol of sweetgourd.

Regeneration from both the varieties were significantly influenced by different concentrations of BAP. The highest shoot induction rate was obtained from $4.44 \mu \mathrm{M}$ BAP followed by $2.22 \mu \mathrm{M}$ BAP for BARI Mistikumra-1 (Table 2 and Fig. 1A). In contrast, the highest percentage of regeneration with minimum days to shoot induction was observed in $8.88 \mu \mathrm{M}$ BAP for BARI Mistikumra-2 (Table 2, Fig. 2A). Krug et al. (2005) reported in vitro organogenesis of watermelon with higher efficiency, when cotyledon segments from the proximal region collected from 3-day-old seedlings were cultivated in MS with $1 \mathrm{mg} / \mathrm{l} \mathrm{BAP}$ $(4.44 \mu \mathrm{M})$ and coconut water $(10 \%)$. But Zhao (1999) observed that the explants of cotyledonary base from 4-day-old seedlings of $C$. moschata incubated on medium containing $4.0 \mathrm{mg} / \mathrm{l} \mathrm{BAP}(17.76 \mu \mathrm{M})$ and $0.4 \mathrm{mg} / \mathrm{l} \mathrm{IAA}(2.28 \mu \mathrm{M})$ showed the best shoot induction (50\%) which was lower than that observed in the present study. The highest frequency $(63.7 \%)$ and the average time $(11.0 \pm 1.03$ days) for shoot

Table 2. Effect of BAP on shoot induction from cotyledon explants of sweetgourd (mean values).

\begin{tabular}{|c|c|c|c|c|c|c|}
\hline \multirow[b]{2}{*}{$\begin{array}{l}\text { BAP } \\
(\mu \mathrm{M})\end{array}$} & \multicolumn{3}{|c|}{ BARI Mistikumra-1 } & \multicolumn{3}{|c|}{ BARI Mistikumra-2 } \\
\hline & $\begin{array}{c}\text { \% of } \\
\text { shoot } \\
\text { induction }\end{array}$ & $\begin{array}{c}\text { Days for } \\
\text { shoot } \\
\text { induction }\end{array}$ & $\begin{array}{l}\text { No. of } \\
\text { shoots/ } \\
\text { explant }\end{array}$ & $\begin{array}{c}\text { \% of } \\
\text { shoot } \\
\text { induction }\end{array}$ & $\begin{array}{c}\text { Days for } \\
\text { shoot } \\
\text { induction }\end{array}$ & $\begin{array}{l}\text { No. of } \\
\text { shoots/ } \\
\text { explant }\end{array}$ \\
\hline Control & $0.00 \mathrm{e}$ & $0.00 \mathrm{e}$ & $0.00 c$ & $0.00 c$ & $0.00 c$ & $0.00 \mathrm{c}$ \\
\hline 2.22 & $86.7 \mathrm{~b}$ & $17.3 \mathrm{c}$ & $6.4 b$ & $58.3 \mathrm{ab}$ & $8.5 b$ & $7.5 \mathrm{ab}$ \\
\hline 4.44 & $94.4 \mathrm{a}$ & $14.7 \mathrm{~d}$ & $8.9 a$ & $61.1 \mathrm{ab}$ & $10.7 \mathrm{a}$ & $8.4 \mathrm{ab}$ \\
\hline 6.66 & $76.4 \mathrm{c}$ & $20.1 b$ & $6.5 b$ & $50.0 \mathrm{~b}$ & $10.4 a$ & $6.1 \mathrm{~b}$ \\
\hline 8.88 & $68.6 \mathrm{~d}$ & $23.8 \mathrm{a}$ & $5.9 \mathrm{~b}$ & $83.3 a$ & $8.4 b$ & $11.9 \mathrm{a}$ \\
\hline
\end{tabular}

Means followed by different letters within a column are significantly different at $\mathrm{p}<0.05$.

regeneration in pumpkin (C. moschata) were reported earlier from seven-day-old cotyledon explants cultured on MS containing $0.5 \mathrm{mg} / \mathrm{l}$ BAP $(2.22 \mu \mathrm{M})$ (Zhang et al. 2008). This might have caused due to differences in cultivars and culture conditions. The highest number of shoots (8.9) per explant in the present study was also observed in $4.44 \mu \mathrm{M}$ BAP which was statistically different than other concentrations of BAP for BARI Mistikumra-1. In contrast, the highest number of shoots (11.9) was recorded in $8.88 \mu \mathrm{M}$ BAP for BARI Mistikumra-2 (Table 2, Figs 1B, 2B). But Ahmad and Anis (2005) observed similar number of shoots (8.80 \pm 0.27 ) in MS with $1.0 \mu \mathrm{M} \mathrm{BA}+\mathrm{CH} 200 \mathrm{mg} / \mathrm{l}$ from nodal explants of cucumber. 

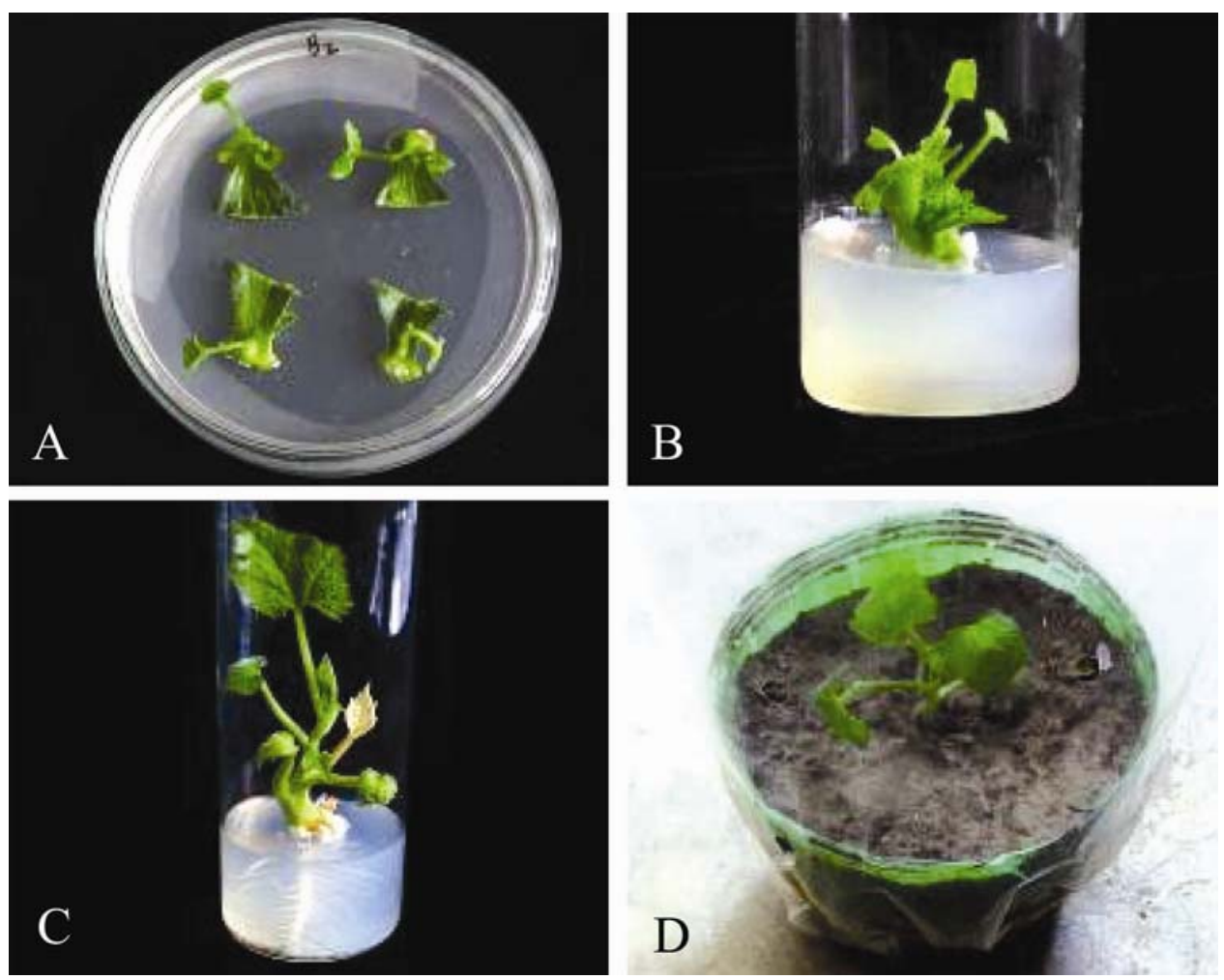

Fig. 1A-D. Regeneration of BARI Mistikumra-1. (A) Shoot initiation on 4.44 $\mu \mathrm{M}$ BAP, (B) multiple shoot formation on $4.44 \mu \mathrm{M}$ BAP, (C) well developed rooted plantlet on 0.53 $\mu \mathrm{M}$ NAA and (D) hardening of plantlets in greenhouse.

Root growth was observed within 3 weeks after the placement of elongated shoots $(2.0-2.5 \mathrm{~cm})$ on rooting medium. Among the three different rooting media the percentage of rooting was variable for both the varieties. The highest percentage of rooting was observed in MS supplemented with $0.53 \mu \mathrm{M}$ NAA followed by half-strength MS for both BARI Mistikumra 1 and BARI Mistikumra 2 , respectively while the lowest rooting frequency was observed in $2.46 \mu \mathrm{M}$ IBA for both BARI Mistikumra 1 and BARI Mistikumra 2, respectively (Table 3). Wei et al. (2006) and Sultana et al. (2004) found similar results in watermelon (Citrullus lanatus Thumb.) where the highest rooting frequency (95\%) was recorded in $0.1 \mathrm{mg} / \mathrm{l}$ NAA $(0.53 \mu \mathrm{M})$. Pal et al. (2007) also observed $59.33 \%$ rooting frequency in $0.5 \mathrm{mg} / \mathrm{l} \mathrm{IBA}(2.46 \mu \mathrm{M})$ of summer squash (C. pepo).

Akther et al. (2007) observed 100\% of rooting in MS without growth regulators for sweetgourd. Our results also showed better rooting frequency in growth regulator free medium than that obtained from the medium supplemented with IBA (Table 3). Rooting in plant growth regulator-free 
medium during organogenesis has been reported earlier in C. pepo (Ananthakrishnan et al. 2003) and (Lee et al. 2003).

Table 3. Effect of different concentrations of plant growth regulators on root induction of sweetgourd (mean values).

\begin{tabular}{lccccc}
\hline $\begin{array}{l}\text { Growth } \\
\text { regulators }\end{array}$ & \multicolumn{2}{c}{ BARI Mistikumra-1 } & & \multicolumn{2}{c}{ BARI Mistikumra-2 } \\
\cline { 2 - 3 } \cline { 5 - 6 }$(\mu \mathrm{M})$ & $\begin{array}{c}\text { \% of rooting } \\
\text { frequency }\end{array}$ & $\begin{array}{c}\text { Days for root } \\
\text { induction }\end{array}$ & & $\begin{array}{c}\text { \% of rooting } \\
\text { frequency }\end{array}$ & $\begin{array}{c}\text { Days for root } \\
\text { induction }\end{array}$ \\
\hline $1 / 2 \mathrm{MS}$ & $87.7 \mathrm{~b}$ & $14.2 \mathrm{~b}$ & & $80.0 \mathrm{~b}$ & $14.4 \mathrm{a}$ \\
$0.53 \mathrm{NAA}$ & $92.6 \mathrm{a}$ & $12.3 \mathrm{c}$ & & $93.3 \mathrm{a}$ & $8.6 \mathrm{~b}$ \\
$2.46 \mathrm{IBA}$ & $70.3 \mathrm{c}$ & $18.4 \mathrm{a}$ & & $76.7 \mathrm{c}$ & $10.2 \mathrm{~b}$ \\
\hline
\end{tabular}

Means followed by different letters within a column are significantly different at $p<0.05$.
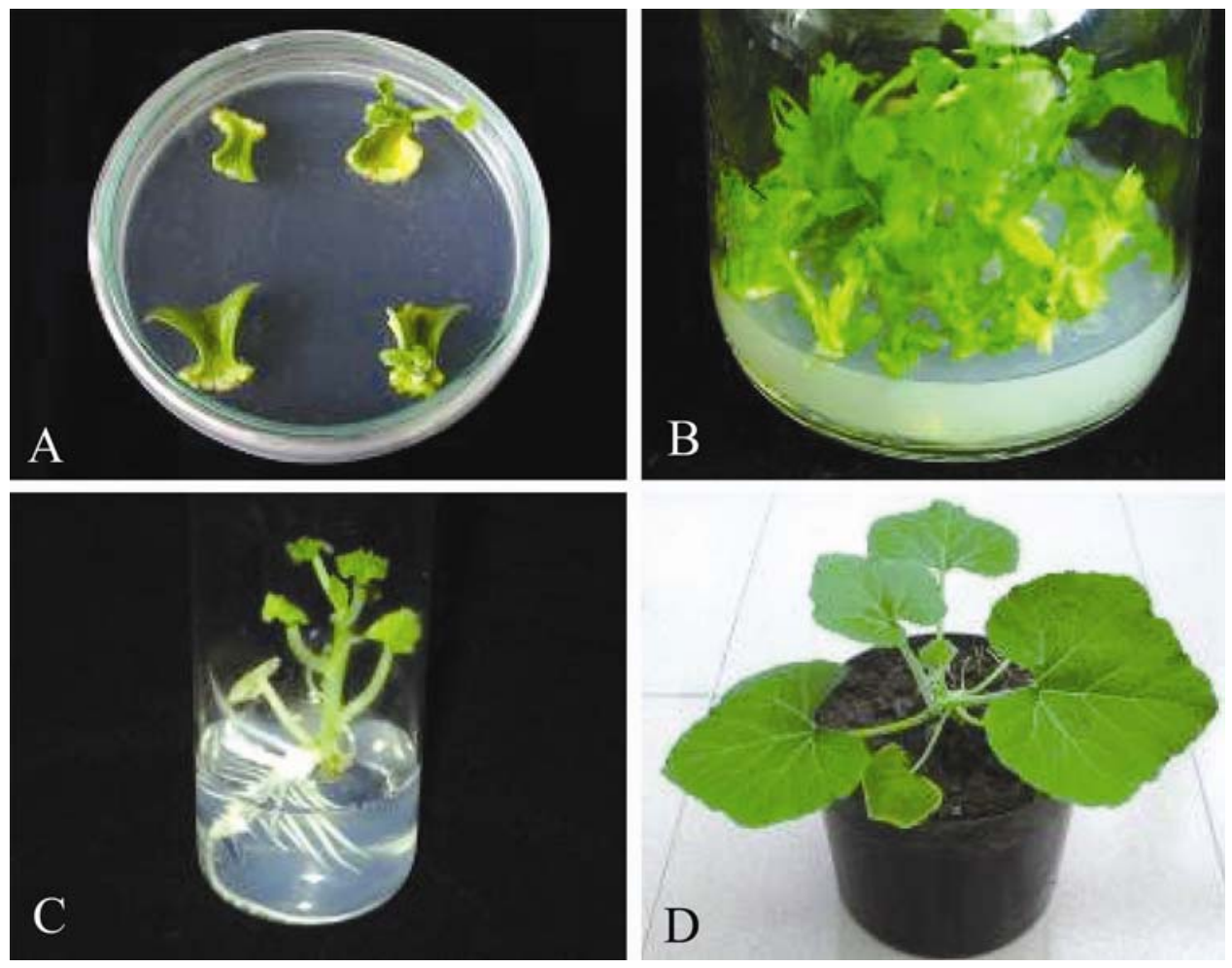

Fig. 2A-D. Regeneration of BARI Mistikumra-2. (A) Shoot initiation on $8.88 \mu \mathrm{M}$ BAP, (B) multiple shoot formation on $8.88 \mu \mathrm{M}$ BAP, (C) well developed rooted plantlet on 0.53 $\mu \mathrm{M}$ NAA and (D) hardened plantlet in greenhouse.

The duration for root formation was delayed in the rooting medium without any auxin. Minimum number of days required for rooting was 12.3 in BARI Mistikumra-1 whereas it was 8.6 in BARI Mistikumra-2 when the shoots were 
cultured on $0.53 \mu \mathrm{M}$ NAA (Table 3, Fig.1C, 2C). Akther et al. (2007) showed the minimum number of days required for rooting of C. moschata was 6.63 in MS without growth regulators. Zhang et al. (2008) found that the least number of days required for root induction was $6 \pm 0.8$ in MS without growth regulators. Previously it was reported that rooting response may vary with different genotypes, different conditions of shoots used, variation in medium, number of subcultures and culture conditions (Shakti et al. 2007). After rooting, the healthy rooted plantlets were transferred to greenhouse for hardening (Figs 1D, 2D). Following 2 - 3 weeks of acclimation, the plantlets were transferred to the field for further growth and development.

\section{References}

Abrei AL and Staden JV (2001) Development of regeneration protocols for selected cucurbit cultivars. Plant Growth Regul. 35: 263-267.

Ahmad N and Anis M (2005) In vitro mass propagation of Cucumis sativus L. from nodal explants. Turkish J. Bot. 29(3): 237-240.

Akhter J, Haque MS and Karim MA (2007) Plantlet regeneration from seedling explants of sweet gourd. Prog. Agric. 18(2): 61-66.

Ananthakrishnan G, Xia X, Elman C, Singer S, Paris HS, Gal-On A and Gaba V (2003) Shoot production in squash (Cucurbita pepo) by in vitro organogenesis. Plant Cell Rep. 21: 739-746.

Carol G, Baodi X and Dennis G (1995) Somatic embryogenesis and regeneration from cotyledon explants of six squash cultivars. HortScience 30: 1295-1297.

Compton ME (2000) Interaction between explant size and cultivar affects shoot organogenic competence of watermelon cotyledons. HortScience 35(4): 749-750.

Curuk S, Elman C, Schlarman E, Sagee O, Shomer I, Cetiner S, Gray DJ and Gaba V (2002) A novel pathway of rapid shoot regeneration from the proximal zone of the hypocotyl of melon (Cucumis melo L.). In vitro Cell Dev. Biol. Plant 38: 260-267.

Debeaujon I and Branchard M (1993) Somatic embryogenesis in Cucurbitaceae. Plant Cell, Tiss. and Org. Cult. 34: 91-100.

Ficcadenti N and Rotino GL (1995) Genotype and medium affect shoot regeneration of melon. Plant Cell. Tiss. Org. Cult. 40: 293-295.

Gambley RL and Dodd WA (1991) The influence of cotyledon in axillary and adventitious shoot production from cotyledonary nodes of Cucumis sativus L. (Cucumber). J. Expt. Bot. 42: 1131-1135.

Hegazi HH (1999) Genotypic differences in callus formation and shoot forming capacity of some vegetable species. Arab Univ. J. Agric. Sci. 7(2): 507-520.

Krug MGZ, Stipp LCL., Rodriguez APM and Mendes, BMJ (2005) In vitro organogenesis in watermelon cotyledons. Pesq. agropec. bras., Brasília. 40(9): 861-865.

Lee YK, Chung WI and Ezura H (2003) Efficient plant regeneration via organogenesis in winter squash (Cucurbita maxima Duch.). Plant Sci. 164: 413-418. 
Pal SP, Alam I, Anisuzzaman M, Sarker KK, Sharmin SA and Alam MF (2007) Indirect organogenesis in summer squash (Cucurbita pepo L.). Turkish. J. Agric. For. 31: 63-70.

Robinson RW and Walters DSD (1997) Cucurbits. CAB International, Wallingford, UK. 226.

Shakti PP, Iftekhar A, Anisuzzaman M, Kanak KS, Shamima AS and Mohammad FA (2007) Indirect organogenesis in summer squash (Cucurbita pepo L.). Turl. J. Agric. For. 31: 63-70.

Sultana RS, Bari MA, Rahman MH, Siddique NA and Khatun N (2004) In vitro rapid regeneration of plantlets from leaf explants of watermelon (Citrullus lanatus Thumb.). Biotechnol. 3(2): 131-135.

Wei L, Jian C, MaoYing MZ and Wei W (2006) Tissue culture and rapid propagation of Trichosanthes kirilowii Maxim. J. Plant Res. Environ. 15(4): 73-74.

Zhang Y, Zhou J, Wu T and Cao J (2008) Shoot regeneration and the relationship between organogenic capacity and endogenous hormonal contents in pumpkin. Plant Cell Tiss. and Org. Cult. 93: 323-331.

Zhao J (1999) In vitro culture of cotyledon explants of Cucurbita moschata. Acta Hortic. Sinica 26(3): 196-197.

Zitter TA, Hopkins DL and Thomas CE (1996) Compendium of Cucurbit Diseases. APS Press, St. Paul, MN USA. 